Original Research Paper

\title{
Pemanfaatan Limbah Cangkang Kerang Untuk Produk Kerajinan Tangan Masyarakat Pesisir
}

\author{
Salim Abubakar ${ }^{1 *}$, Masykhur Abdul Kadir ${ }^{1}$, Rugaya H. Serosero ${ }^{1}$, Riyadi Subur ${ }^{1}$, Sri Endah \\ Widiyanti $^{1}$, Adi Noman Susanto ${ }^{1}$, Rina ${ }^{1}$, Reni Tyas Asrining $\mathbf{P}^{1}$ \\ ${ }^{I}$ Program Sudi Manajemen Sumberdaya Perairan Fakultas Perikanan dan Kelautan Universitas Khairun Ternate, \\ Ternate, Indonesia.
}

https://doi.org/10.29303/jpmpi.v3i2.1010

Sitasi: Abubakar, S., Abdul, K. M, Serosero, R. H, Subur. R, Widiyanti. S.E, Susanto. A. N., Rina \& Asrining P. R. T. (2021). Pemanfaatan Limbah Cangkang Kerang Untuk Produk Kerajinan Tangan Masyarakat Pesisir. Jurnal Pengabdian Magister Pendidikan IPA, 4(4)

\author{
Article history \\ Received: 15 September 2021 \\ Revised: 20 September 2021 \\ Accepted: 27 September 2021 \\ *Corresponding Author: Salim \\ Abubakar, Program Sudi \\ Manajemen Sumberdaya \\ Perairan Fakultas Perikanan \\ dan Kelautan Universitas \\ Khairun Ternate, Ternate, \\ Indonesia. Email: \\ mylasrinaldy@gmail.com
}

\begin{abstract}
The shellfish craft business is not only profitable for business actors, but also provides other benefits, including opening up employment opportunities for the community, increasing community creativity due to growing market demand and maintaining the product as a quality work of art. The output targets are household equipment (tissue boxes), interior accessories (wind chimes, door/window curtains) and souvenirs (key chains, brooches). Implementation methods include counseling, demonstration, training and coaching in the development of shellfish waste as a business opportunity. The training activity was successful because the enthusiasm of the participants was so great in pursuing the art of shellfish craft. Various forms of products and models produced are very varied. The products produced are tissue boxes, wind chimes, door/window curtains, key chains and brooches. The formation of a craft group "Creative Kastil" in the context of the sustainability of training activities.
\end{abstract}

Keywords: Waste, shells, shells, handicrafts, coastal communities

\section{Pendahuluan}

Kerang adalah salah satu komoditas laut yang memiliki nilai ekonomis baik daging maupun cangkangnya. Pemanfaatan cangkang kerang sebagai bahan dasar utama pembuatan aneka kerajinan selain bernilai ekonomis, juga berpotensi untuk mengurangi pencemaran lingkungan. Cangkang kerang yang dijadikan sebagai bahan dasar memiliki tekstur yang sangat bagus untuk dibentuk menjadi aneka kerajinan tangan. Kerajinan tangan ini akan menjadi cenderamata yang khas terutama untuk daerah pariwisata wilayah pesisir (Yahya dan Latjompoh, 2020). Pemanfaatan cangkang kerang untuk kerajinan ini, selain untuk menambah nilai ekonomis produk (Ridho et al., 2016), juga sekaligus untuk menjaga kelestarian lingkungan (Fitri dan Rusmini, 2017). Pemanfaatan cangkang kerang juga dapat mengurangi resiko pencemaran lingkungan (Hardjanto, 2020).

Limbah padat kerang berupa cangkang selama ini lebih banyak dimanfaatkan sebagai bahan kerajinan seperti sebagai materi hiasan dinding atau materi desain interior. Pemanfaatan lain yang sudah dikembangkan adalah menjadi campuran pakan ternak (Agustini et al., 2011). Limbah cangkang memiliki potensi dan peluang yang sangat besar untuk meningkatkan perekonomian masyarakat pesisir. Pembuatan kerajinan bros mampu memperdayakan limbah hasil laut. Pendayagunaan modal sosial tersebut dapat menjadi media pemberdayaan masyarakat dan penciptaan lapangan kerja. Berbagai produk 
yang dapat dihasilkan dari cangkang moluska antara lain, souvenir, aksesoris perhiasan (cincin, gelang, kalung,anting, bros dan hiasan rambut), furniture dengan tempelan atau inclay cangkang moluska, dan masih banyak lagi jenis kerajinan yang memakai bahan dasar atau bahan pelapis dari cangkang moluska. Banyaknya produkproduk yang dapat dihasilkan dari cangkang moluska, menunjukan bahwa cangkang moluska penting dalam kehidupan masyarakat kita (Erwin, 2013; Musapasan dan Amalia, 2020).

Usaha kerajinan kerang selain mendatangkan keuntungan bagi pelaku usaha, juga memberikan manfaat lainnya antara lain membuka lapangan pekerjaan bagi masyarakat, meningkatkan kreativitas masyarakat karena permintaan pasar yang berkembang dan mempertahankan produk tersebut sebagai salah satu karya seni yang bermutu. Peminat kerajinan kerang tidak hanya di pasar domestik, tetapi juga sampai ke Eropa dan Amerika. Produk kerajinan kerang memiliki nilai ekonomi tinggi dalam perdagangan internasional. Pemasaran produk juga dilakukan melalui pameran (expo) dari tingkat lokal, nasional hingga internasional (Dewi, 2010).

Kelurahan Kastela merupakan salah satu kelurahan yang berada di wilayah pesisir yang memiliki potensi sumber daya alam yang memadai untuk mendukung perekonomian, terutama pada sektor kelautan. Untuk sektor kelautan yang telah digarap adalah bidang perikanan sebagai mata pencaharian masyarakat. Sementara itu, potensi lainnya seperti kulit-kulit kerang yang beraneka ragam sama sekali belum dimanfaatkan sehingga terbuang menjadi limbah. Padahal, beragam jenis cangkang kerang dengan bentuk dan warna yang unik berpeluang besar untuk diolah dan dimanfaatkan sebagai bahan baku berbagai jenis produk seni kerajinan. Oleh sebab itu, diperlukan upaya untuk memperdayakan masyarakat dalam mengolah limbah-limbah cangkang kerang menjadi produk- produk seni kerajinan kreatif yang bisa diperdagangkan, karena Kelurahan Kastela memiliki wisata pantai. Untuk mendukung kawasan wisata tersebut, maka keberadaan seni kerajinan kerang menjadi penting, terutama dalam penyediaan cenderamata atau souvenir.

Permasalahan mitra adalah masyarakat belum melihat potensi ekonomi dari keberadaan beragam jenis dan bentuk limbah cangkang kerang tersebut sehingga hanya menjadi limbah. Hal tersebut disebabkan karena masyarakat Kelurahan Kastela memang belum memiliki keterampilan dasar untuk mengolah limbahlimbah cangkang kerang menjadi produk-produk seni kerajinan yang unik dan memiliki nilai ekonomi. Limbah-limbah cangkang kerang dapat diolah menjadi produk-produk seni kerajinan yang unik dan hasilnya banyak diminati konsumen dari dalam negeri dan luar negeri sehingga memiliki prospek pasar menjanjikan. Permasalahan lainnya adalah berkurangnya kunjungan wisatawan dalam obyek wisata karena salah satu penyebabnya adalah tidak tesedianya souvenir sebagai cendramata yang dapat di bawah pulang oleh wisatawan.

Berdasarkan hal itu, dipandang perlu dilakukannya suatu pembinaan dan pemberdayaan bagi masyarakat Kelurahan Kastela dalam memanfaatkan limbah kerang sebagai produk kerajinan dengan mutu dan kualitas yang cukup baik sehingga mempunyai nilai jual yang cukup tinggi, yang pada akhirnya dapat meningkatkan ekonomi masyarakat pesisir. Target akhir dari PKM ini adalah meningkatkan keahlian dan jumlah perajin serta jenis produksi seni kerajinan kerang melalui rekrutmen perajin pemula dan pembuatan model-model produk baru dengan berbagai variasi bentuk dan fungsi sesuai selera pasar. 


\section{Metode}

\section{Program Kerja}

Pada program pengabdian difokuskan pada pemberdayaan masyarakat Kelurahan Kastela dalam pengembangan seni kerajinan, terutama kerajinan dengan bahan utama limbah cangkang kerang. Secara umum, kegiatan awal yang dilakukan sebagai berikut:

a. Survei Potensi Sumberdaya

Survei potensi sumberdaya dilakukan setelah ditentukan desa mitra yakni Kelurahan Kastela. Tujuan survei potensi sumberdaya adalah untuk menggali dan mengidentifikasi potensi-potensi yang dimiliki kelurahan mitra, sehingga dapat ditentukan jenis program utama yang tepat untuk dikembangkan.

b. Sosialisasi Program

Sosialisasi program bertujuan untuk mengomunikasikan program yang direncanakan kepada masyarakat melalui aparat desa untuk memperoleh persetujuan. Melalui sosialisasi program juga dapat disepakati tentang durasi waktu dan jenis kegiatan yang akan dilaksanakan beserta target-target yang ditetapkan sebagai tolok ukur keberhasilan program.

c. Pembentukan Kelompok Perajin

Pembentukan kelompok perajin dilakukan dengan menjaring anggota - anggota masyarakat yang memiliki minat untuk menekuni bidang seni kerajinan, kemudian dibuatkan organisasi dalam bentuk kelompok perajin dengan nama tertentu yang menjadi pendukung utama dari program pengembangan seni kerajinan kerang yang akan dilaksanakan.

\section{Pelaksanaan Kegiatan}

Dalam pelaksanaan kegiatan Program Kemitraan Masyarakat (PKM) Kubermas Tematik dengan melibatkan seluruh mahasiswa yang melakukan Kubermas di Kelurahan Kastela dan Kelurahan Jambula. Bentuk kegiatan aksi Program Pengabdian Masyarakat yang dilaksanakan

adalah pelatihan keterampilan dasar pembuatan produk-produk seni kerajinan kerang bagi kelompok perajin Kelurahan Kastela. Kegiatan tersebut dilakukan dalam bentuk workshop melalui beberapa tahapan berikut:

1. Sosialisasi program kepada masyarakat Kelurahan Kastela.

2. Penyampaian materi untuk memberikan wawasan atau pengetahuan dasar tentang seni kerajinan yang mencakup: pengertian atau lingkup seni kerajinan, fungsi dan manfaat seni kerajinan dalam kehidupan, jenis-jenis seni kerajinan, dan prospek pasar produkproduk seni kerajinan, terutama seni kerajinan kerang. Materi ini bertujuan untuk memotivasi peserta dalam menekuni seni kerajinan secara sungguh-sungguh hingga menjadi perajin terampil.

3. Persiapan jenis-jenis peralatan yang dibutuhkan untuk memproduksi modelmodel seni kerajinan kerang.

4. Persiapan bahan utama yang berupa jenisjenis kerang melalui proses identifikasi, seleksi bentuk dan ukuran kerang, dan pembersihan kerang-kerang yang dipilih hingga siap digunakan sebagai bahan baku.

5. Proses pembentukan produk yang mencakup: pembuatan bentuk dasar, perakitan atau penempelan kerang pada bentuk dasar, dan fiksasi bentuk produk.

6. Proses finishing secara natural atau dengan warna untuk menghasilkan finishing produk yang berkualitas dan bervariasi.

7. Penyajian produk sebagai kegiatan penutup.

Jenis produk seni kerajinan kerang yang dibuat dalam pelatihan keterampilan dasar tersebut adalah produk-produk dengan bentuk sederhana, seperti: perlengkapan rumah tangga (Boks tissue), assesories interior (lonceng angin, tirai pintu/jendela) dan cendratama (gantungan kunci, bros). Tim pengabdi akan membuat contoh model atau bentuk dasar dari masing-masing produk tersebut untuk diikuti oleh peserta pelatihan melalui proses pembimbingan. Dengan penguasaan keterampilan dasar dan contoh-contoh produk yang diberikan, maka peserta diharapkan bisa mengembangkan secara mandiri sehingga terjadi kontinuitas produksi pada kelompok perajin yang dilatih. Keberlanjutan program pengembangan seni kerajinan kerang di Kelurahan Kastela, maka dilakukan pemantauan atau pendampingan sewaktu-waktu.

\section{Hasil dan Pembahasan}

\section{Sosialisasi Program}

Sosialisasi program bertujuan untuk memberitahukan program pelatihan keterampilan dasar kerajinan kerang yang hendak dilakukan kepada masyarakat Kelurahan Kastela Kecamatan Pulau Ternate Kota Ternate. Sosialisasi program dilakukan dalam dua tahap. Sosialisasi pertama hanya dilakukan secara terbatas kepada Kepala Kelurahan beserta stafnya, dengan tujuan menyampaikan secara 
umum metode pelatihan yang akan dilakukan melalui Program Kemitraan Masyarakat (PKM) Kubermas Tematik. Dari sosialisasi ini diperoleh 15 orang warga kelurahan berjenis kelamin perempuan yang berminat mengikuti pelatihan dasar kerajinan kerang. Sosialisasi kedua dilakukan secara langsung kepada 15 warga desa yang yang berminat mengikuti pelatihan dasar keterampilan kerajinan kerang. Sosialisasi ini bertujuan untuk memberitahukan bentuk kegiatan dan materi-materi pelatihan yang akan dilaksanakan yaitu pengolahan limbah cangkang kerang untuk produk kerajinan. Selain warga yang terlibat dalam pelatihan, juga mahasiswa Kubermas Universitas Khairun sebanyak 30 orang yang bertugas mulai dari proses persiapan pelatihan sampai dengan pendampingan warga dalam pembuatan produk kerajinan limbah cangkang kerang.

\section{Pembekalan Pengetahuan Dasar Seni Kerajinan}

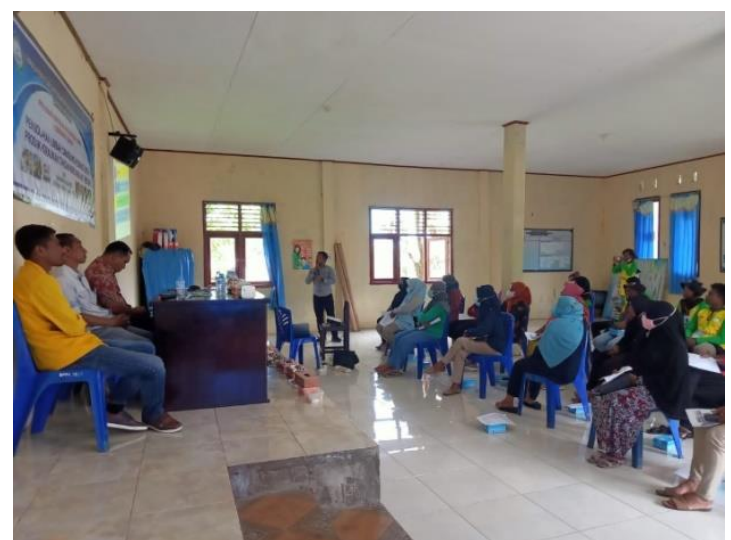

\section{Gambar 1. Pembekalan pengetahuan dasar seni kerajinan}

\section{Pengolahan Limbah Cangkang Kerang Sebagai Produk Kerajinan}

Dalam pelaksanaan pembuatan jenis produk, alat dan bahan yang dibutuhkan disiapkan pada setiap jenis produk sehingga para peserta pelatihan dengan mudah mendapatkan alat dan bahan tersebut. Ketersediaan alat dan bahan merupakan salah satu faktor dalam menentukan keberhasilan proses pembuatan berbagai produk seni kerajinan (Muhammad et al., 2020).

Setelah semua alat dan bahan disiapkan, selanjutnya dilakukan pembagian lima kelompok berdasarkan jenis produk yang akan dibuat yaitu kelompok (produk box tissue, produk lonceng angin, produk tirai pintu/jendela, produk gantungan kunci, produk bros). Pembagian kelompok tersebut bertujuan agar setiap peserta benar-benar dapat menguasai jenis produk tersebut dan mengembangkan kreativitasnya. Dengan metode ini, pelatihan dapat berjalan lebih efektif, karena di antara peserta akan saling
Pembekalan pengetahuan dasar seni kerajinan bertujuan untuk menambah wawasan kepada peserta pelatihan sebagai bekal dalam melakukan praktek seni kerajinan dan juga memotivasi peserta dalam menekuni seni kerajinan secara sungguh-sungguh hingga menjadi perajin terampil.

Kegiatan ini dilakukan dalam bentuk penyajian materi (presentasi) dan diskusi. Materi yang disajikan berupa : potensi sumerdaya moluska, ruang lingkup moluska, manfaat gastropoda dan bivalva, manfaat limbah kerang, aneka produk kerajinan limbah cangkang kerang, peranan dan permasalahan kerajinan limbah kerang, bahan dan alat serta metode pembuatan produk dan prospek pasar produk seni kerajinan. Dari kegiatan ini, diharapkan peserta pelatihan memiliki pengetahuan dasar dan menambah antusiasme dalam pembuatan beragam jenis seni kerajinan sebagai salah satu sumber penghasilan tambahan

berinteraksi dan mengevaluasi hasil kerjanya pada tiap tahap. Peserta kemudian dibimbing oleh mahasiswa Kubermas yang sudah dilatih sebelumnya

Keterlibatan mahasiswa kubermas dalam kegiatan Program Kemitraan Masyarakat (PKM) Kubermas Tematik, selain membatu tim pengabdi (dosen), juga untuk memberikan pengalaman kepada mahasiswa dalam memperdayakan masyarakat sesuai dengan keahlian dan bidang ilmu yang mereka peroleh di kampus. Dengan pengalaman tersebut, mahasiswa diharapkan dapat memahami berbagai potensi dan persoalan yang dihadapi masyarakat, sehingga ketika menjadi sarjana menjadi lebih siap dalam beradaptasi dan berpartisipasi dalam memecahkan persoalan yang dihadapi masyarakat. Keterlibatan mahasiswa terutama difokuskan sebagai instruktur bagi peserta pelatihan. Prosesn pelatihan dan pembimbingan dapat dilihat pada gambar 1, $2,3,4,5$. 


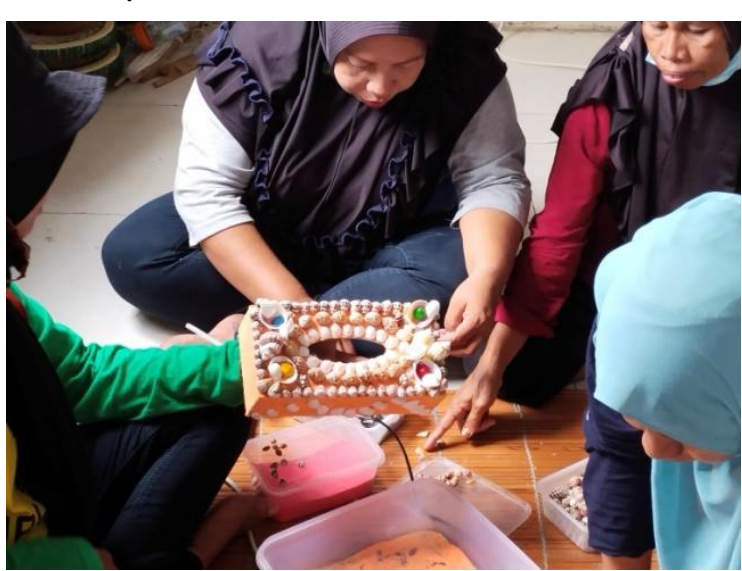

Gambar 1. Proses pelatihan pembuatan Produk box tissue

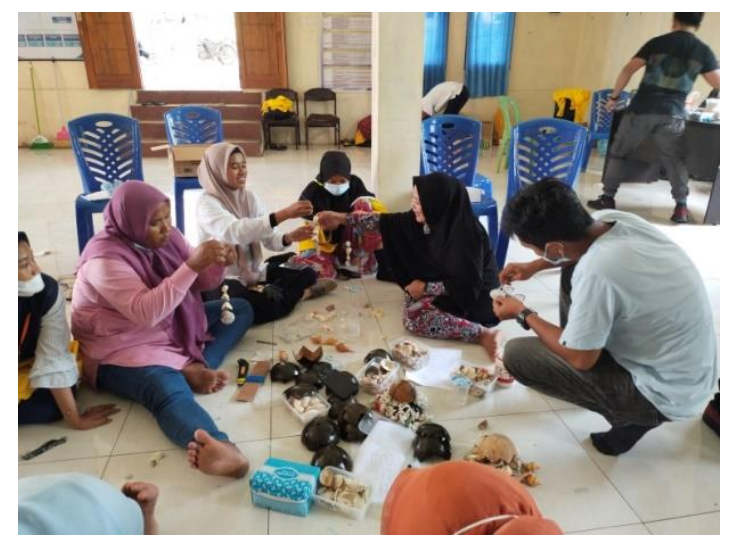

Gambar 3. Proses pelatihan pembuatan produk tirai pintu/jendela

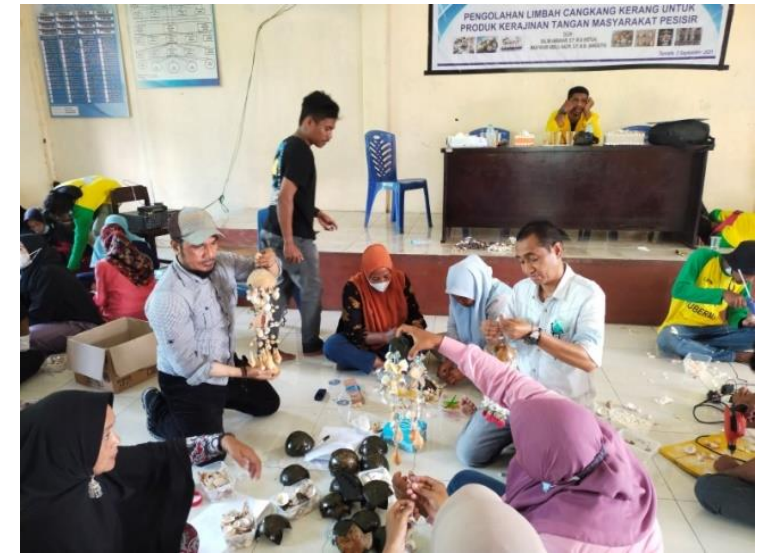

Gambar 2. Proses pelatihan pembuatan produk lonceng angin

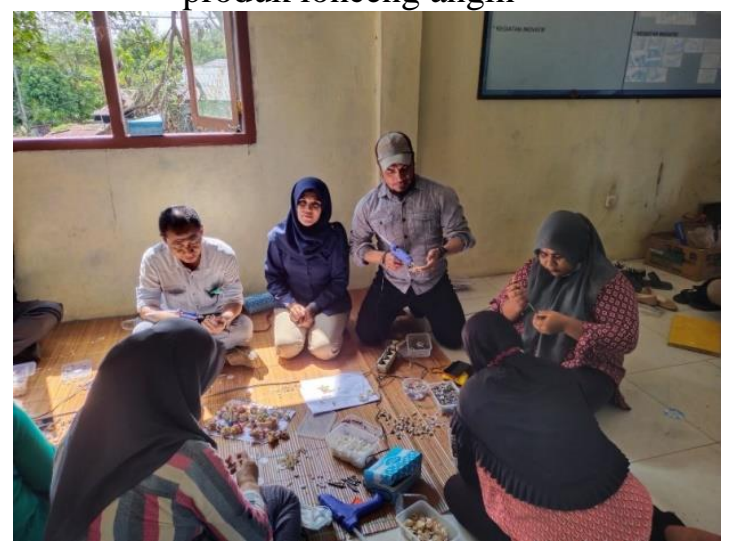

Gambar 4. Proses pelatihan pembuatan produk gantungan kunci

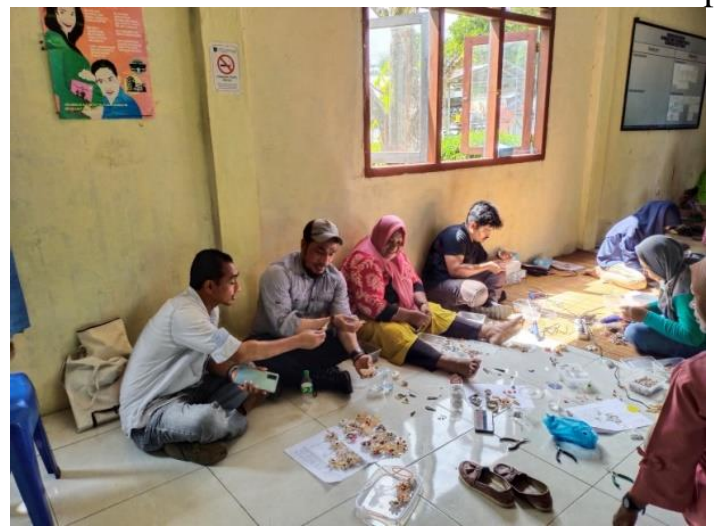

Gambar 5. Proses pelatihan pembuatan produk bros

Melalui pelatihan dan bimbingan intensif dalam setiap tahapan proses pembentukan produk kerajinan, para peserta pelatihan berhasil membuat aneka macam bentuk produk seni kerajinan kerang sesuai dengan model yang dipilih. Kegiatan ini dianggap berhasil karena berbagai macam bentuk produk yang dihasilkan oleh peserta sangat bervariasi modelnya. Model produk yang dihasilkan tidak kalah bersaing dengan pengrajin yang sudah terampil di luar wilayah Propinsi Maluku Utara. Peserta pelatihan begitu bersemangat dan antusiasme dalam menekuni keterampilan seni kerajinan kerang, ketika mendapatkan kendala pembuatan produk langsung ditanyakan dan diskusikan sesame kelompok. Adanya semangat dan antusiasme itu merupakan modal mental dalam pengembangan seni kerajinan di masa mendatang. Hasil aneka produk kerajinan yang telah dibuat, selanjutnya dipresentasikan oleh masing-masing ketua kelompok dengan menyampaikan kekurangan, kelebihan, tingkat kesulitan dan kemudahan dalam pembuatan produk serta pesan dan kesan diadakan pelatihan. 


\section{Proses Finishing dan Produk Hasil Pelatihan}

Proses finishing merupakan kegiatan akhir dari rangkaian tahapan pelatihan pembuatan produk seni kerajinan. Hal ini bermanfaat untuk menambah keawetan dan keindahan produk agar terlihat lebih menarik bagi konsumen.. Menurut Sudana (2010), bahwa ada beberapa corak finishing untuk produk-produk seni kerajinan, yaitu: finishing natural, finishing berwarna-warni, dan finishing antik.

Proses finishing dalam kegiatan ini menggunakan teknik finishing natural dan finishing berwarna. Proses pembuatan produk kerajinan baik warna maupun model sepenuhnya dilakukan oleh peserta sehingga diperoleh berbagai variasi warna dan model produk kerajinan. Cangkang kerang yang digunakan umumnya berwarna alami (gastropoda/siput) dan sebagian ada yang di warnai (kerang/bia) dengan menggunakan cat minyak. Finishing yang dilakukan hanya berfungsi menguatkan hasil tempelan kerang dan menambah nilai kilap. Produk kerajinan limbah cangkang kerang hasil pelatihan dapat di lihat pada Gambar 6, 7, 8, 9 dan 10 .

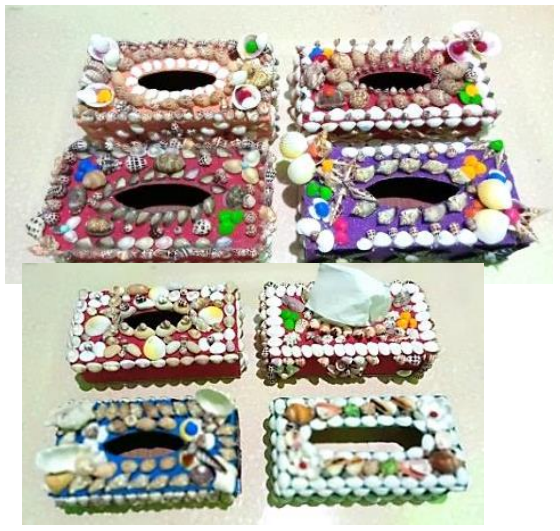

Gambar 6. Produk kerajinan box tissue

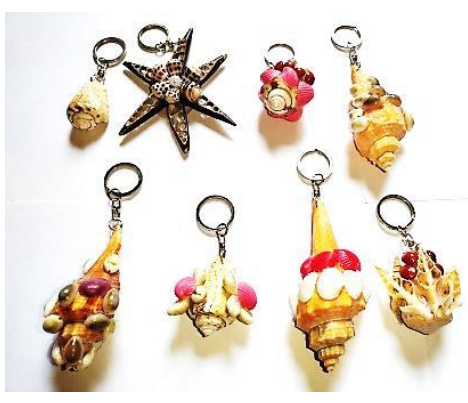

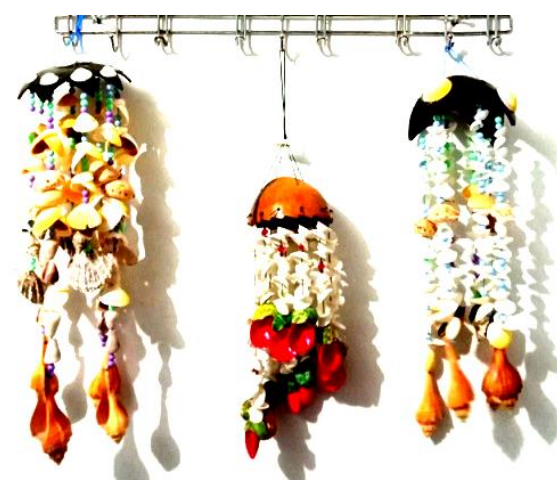

Gambar 7. Produk kerajinan lonceng angin
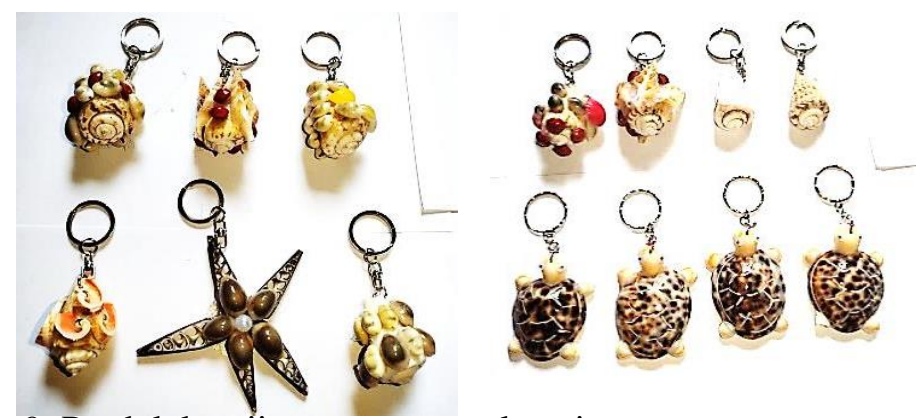

Gambar 9. Produk kerajinan gantungan kunci

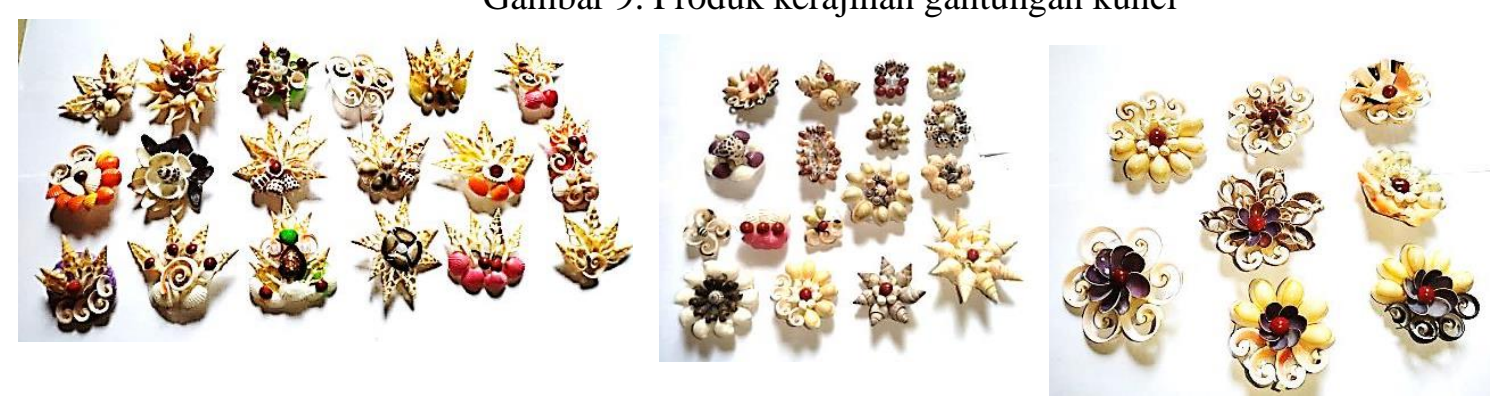

Gambar 10. Produk kerajinan bros 
\begin{tabular}{lll}
\multicolumn{2}{c}{ Berbagai bentuk dan model produk } \\
kerajinan dari & hasil pelatihan
\end{tabular} pada Gambar 9 - 13, terlihat umumnya beragam jenis kerang yang dimanfaatkan sebagai produk tetap dibiarkan berwarna natural (alami). Kerang tersebut hanya dilapisi clear netral sehingga terlihat mengkilap. Umumnya konsumen banyak menyukai jenis finishing natural, akan tetapi agar lebih berkualitas hasil produk kerajinan maka perlu dilakukan inovasi berbagai model dan warna. Oleh karena itu, akan dilakukan pelatihan lanjutan sesuai dengan roadmap pengabadian yang telah ditetapkan, terutama setelah terbentuknya kelompok perajin.

\section{Pembentukan Kelompok Perajin}

Dalam rangka keberlanjutan kegiatan pelatihan, maka dibentuk kelompok perajin yang berguna untuk meningkatkan keterampilan dan kreativitas perajin serta dapat mengembangkan seni kerajinan kerang khususnya di Kelurahan Kastela Kecamatan Pulau Ternate Kota Ternate. Pembentukan kelompok perajin sangat penting untuk pengembangan seni kerajinan, karena dengan adanya kelompok akan mampu meningkatkan kapasitas produksi dan melayani permintaan konsumen yang lebih besar (Muhammad et al., 2020).

Pembentukan kelompok perajin dilakukan setelah selesainya kegiatan pelatihan. Berdasarkan musyawarah dari semua peserta dan Kepala Kelurahan maka diperoleh kelompok perajin dengan nama "Kastil Kreatif". Kelompok tersebut, nantinya tidak hanya bergerak di bidang seni kerajinan kerang tetapi juga jenis-jenis seni kerajinan lainnya berdasarkan potensi sumberdaya alam yang dimiliki Kelurahan Kastela. Semua peserta pelatihan bersedia masuk dalam struktur organisai Kelompok perajin Kasteal Kreatif yang beranggotakan 15 orang.

Pelaksanaan Program Kemitraan Masyarakat (PKM) Kubernas Tematik dengan tema "Pengolahan Cangkang Kerang Sebagai Produk Kerajinan Masyarakat Pesisir" merupakan pelatihan perdana dalam upaya pengembangan sektor seni kerajinan limbah cangkang kerang khususnya di Kelurahan Kastela, sehingga harus dilakukan pembinaan secara berkala terhadap kelompok perajin yang sudah terbentuk agar keberlanjutan program dapat berjalan dengan baik. Hal ini menjadi kesepakatan bersama antara pihak perajin, pihak kelurahan dan pihak Fakultas Perikanan dan Kelautan Universitas Khairun Ternate menjadikan kelompok "Kastil Kreatif" sebagai kelompok binaan Fakultas Perikanan dan Kelautan. Kesepakatan ini dituangkan dalam Surat Keputusan Dekan tentang Struktur organisasi kepengurusan. Adapun susunan struktur organisasi disajikan pada Gambar 11

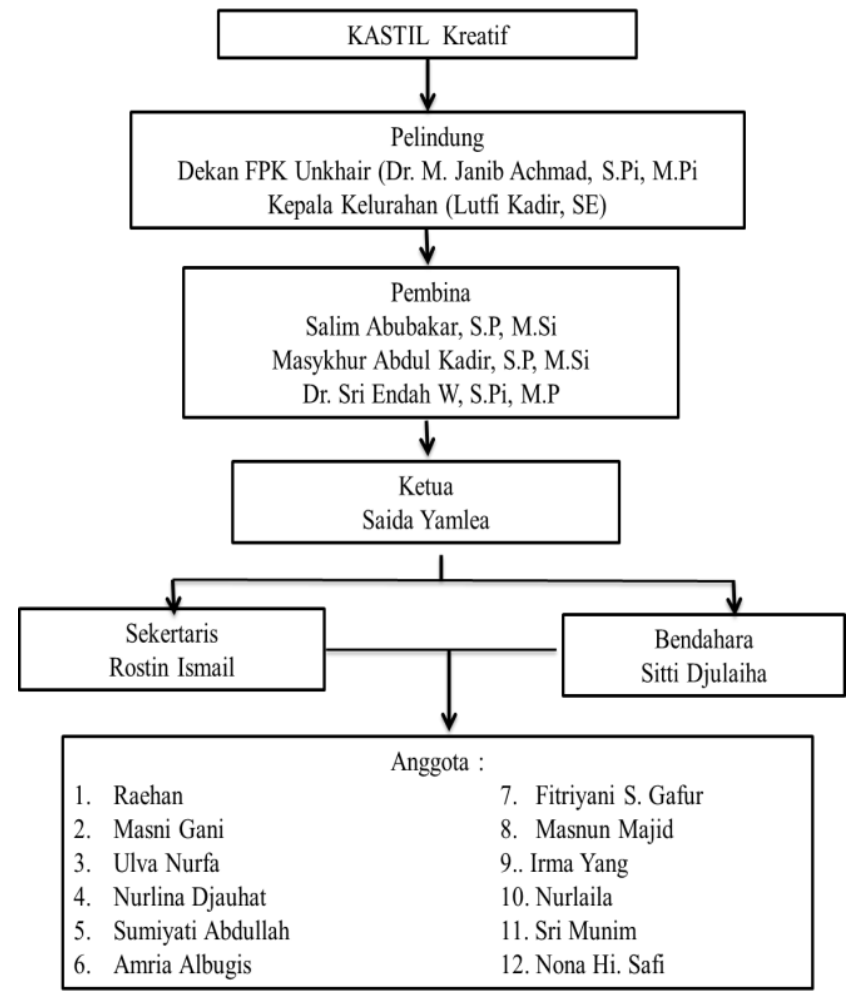

Gambar 11. Struktur Organisasi kelompok perajin "Kastil Kreatif"

\section{Kesimpulan}

Berdasarkan tujuan dan metode pelaksanaan yang dilakukan, maka dapat dikemukakan beberapa kesimpulan aebagai berikut:

1. Pelatihan yang telah dilaksanakan memiliki manfaat besar bagi masyarakat untuk meningkatkan daya saing produk. Manfaat bagi Fakultas maupun Universitas akan menambah jejaring dan kepercayaan yang besar dari masyarakat pengguna dunia pendidikan dan intansi pemerintah.

2. Kegiatan pelatihan ini berhasil karena antusiasme peserta begitu besar dalam menekuni keterampilan seni kerajinan kerang. Berbagai 
macam bentuk produk dan model yang dihasilkan sangat bervariasi. Model produk yang dihasilkan tidak kalah bersaing dengan pengrajin yang sudah terampil di luar wilayah Propinsi Maluku Utara. Produk yang dihasilkan berupa box tissue, lonceng angina, tirai pintu/jendela, gantungan kunci dan bros.

3. Terbentuknya kelompok perajin "Kastil Kreatif" dalam rangka keberlanjutan kegiatan pelatihan.

\section{Ucapan Terimakasih}

Penulis menghaturkan terima kasih yang setinggi-tingginya kepada LPPM atas dukungan dana yang telah diberikan melalui Skema Program Kemitraan Masyarakat dan juga kepada Kepala Kelurahan Kastela dan Mahasiswa Kubermas atas dukungan dan menfasilitasi kami dalam pelaksanaan PKM.

\section{Daftar Pustaka}

Dewi, D. A. N. N. 2010. Analisis Bioekonomi Untuk Pengelolaan Sumber Daya Kerang Simping (Amusium pleuronectes) Di Kabupaten Batang, Jawa Tengah. Tesis. Program Pasca Sarjana Universitas Diponegoro Semarang.

Erwin, T. 2013. Pengaruh modal sosial terhadap perilaku kewirausahaan; Suatu studi pada pelaku usaha mikro kecil menengah di Kecamatan Kabaruan Kabupaten Kepulauan Talaud. Jurnal Acta Diurna, 2(2), 1-10.

Fitri, N. L. E dan Rusmini. 2017. Karakterisasi Kitosan dari Limbah Kulit Kerang Simping (Amusium pleuronectes). UNESA Journal of Chemistry.

Fitri, N. L. E. dan Rusmini. (2017). Karakterisasi Kitosan dari Limbah Kulit Kerang Simping (Amusium pleuronectes). UNESA Journal of Chemistry.

Hardjanto, K. 2020. Pemanfaatan Limbah Kulit Kerang Sebagai Sumber Ekonomi Rumah Tangga: Studi Kasus di Sabila Craft, Kota Magelang. Buletin Ilmiah "MARINA" Sosial Ekonomi Kelautan dan Perikanan, 6 (2) : 125-132.
Mohamad, I., I. Sudana dan Hasdiana. 2020. Pengembangan Seni Kerajinan Kerang Di Desa Modelomo Kecamatan Kabila Bone Kabupaten Bone Bolango. Laporan Akhir Program Pengabdian Kepada Masyarakat Fakultas Teknik Universitas Negeri Gorontalo. Gorontalo.

Musapana, S dan I. R. Amalia. 2020. Kerajinan Limbah Cangkang Kerang Sebagai Alternatif Pembuatan Bros Ramah Lingkungan Tambakrejo Semarang. ABDI: Jurnal Pengabdian dan Pemberdayaan Masyarakat, 2 (1): 58 - 65. DOI: https://doi.org/10.24036/abdi.v2i1.54

Ridho, R., M. T. K. Swandari dan E. Issusilaningtyas. 2016. Pemanfaatan Limbah Cangkang Kerang Kijing Pilsbryoconcha exilis) dalam Meningkatkan Perekonomian Warga Desa Bulupayung-Kesugihan, Cilacap, Jawa Tengah. Jurnal Ilmiah Pengabdian kepada Masyarakat (Agrokreatif), 3 (1): 17-23.

Sudana, I. W. 2010. "Formulasi Bahan dan Teknik Finishing Untuk ProdukProduk Kriya." Jurnal Teknik, Vol. 8, No. 2, pp. 196-207.

Winarni Agustini, T. W, A.S. Fahmi, I. Widowati dan A, Sarwono. 2011. Pemanfaatan Limbah Cangkang Kerang Simping (Amusium Pleuronectes) Dalam Pembuatan Cookies Kaya Kalsium. Jurnal Pengolahan Hasil Perikanan Indonesia, XIV (1): 8-13 